\title{
AMMATTIYLPEYS TUTKIMUKSEN KOHTEENA
}

JUHA VARILA ja MERJAIKONEN-VARILA(2002)

Ylpeys ja ammattiylpeys tutkimuksen kohteeksi. Ylpeyden tunteen teoreettinen ja empiirinen tarkastelu.

Joensuun yliopiston kasvatustieteiden tiedekunnan julkaisuja.

Kun ammattiylpeys viriää työn tai ammatin opiskelun jossain vaiheessa, opiskelijan motivaatiossa ja arvomaailmassa on tapahtunut merkittävä muutos: hän erottautuu niistä, jotka eivät vielä osaa ja liittyy niihin, jotka jo osaavat. Opiskelija on saavuttanut tason, jossa voi olla ylpeä aikaansaannoksestaan. Samalla hän on sisäistänyt suuren määrän ammatin keskeisiä käytänteitä. Ilmiötä on tuttu, mutta sitä ei ole juurikaan teoretisoitu ennen Joensuun aikuiskoulutusprofessori Juha Varilan käynnistämää tutkimusprojektia.

Varilan kiinnostus tunteitten merkitykseen oppimisen keskeisenä elementtinä näyttää siis edelleen jatkuvan. Varilan mukaan suomalaista elämäntodellisuutta määrittää ja kansan kollektiivisessa tajunnassa edelleen elää pärjäämisen ja selviytymisen tunnemajakka, jonka syvät säikeet nousevat kaukaa protestanttisesta etiikasta. Ihmisen identiteetin pysyvyys ja persoonan psyykkinen jatkuvuus perustuu ensisijassa juuri tunteiden järjestelmään. Tällaisen kultuurisen sosialisaation voimallinen vaikutus jää yksilöltä itseltään pääosin havaitsematta - vain tiedostamisen välityksellä ihminen voi edes vähän irrottautua sen otteesta.
Tätä tehtävää palvelivat Varilan tutkimukset työnilosta (Varila \& Viholainen 2000 sekä Varila ja Lehtosaari 2001). Johdonmukaista onkin ollut ottaa tarkastelun kohteeksi vuorostaan ammattiylpeys. Varila on kumppaninsa Merja Ikonen-Varila kanssa asettanut itselleen haastavan tehtävän kartoittaa ja sanoittaa se psykologinen ja oppimisteoreettinen maisema, johon ammattiylpeys käsitteenä olisi sijoitettavissa.

Empiirisenä aineistona Varilalla ja Ikonen-Varilalla on 161 aikuiskoulutukseen osallistuneen suomalaisen esseet tilanteista, jossa he olivat kokeneet ylpeyden tunnetta toisaalta poikkeuksellisen voimakkaana ja toisaalta tiiviisti "liisteröityinä omaan yhteisöönsä". Jotta voitaisiin ymmärtää ammattiylpeyttä, on ensin tutkittava ylpeyttä.

\section{SOPIIKO AMMATTI- YLPEYTTÄ NÄYTTÄÄ?}

Aineiston analysointi paljasti tutkijoille, että ylpeyden tunne tuottaa ihmisissä - ennakkooletusten mukaisesti - toisaalta liittymisen ja samuudenkokemuksia ja toisaalta erottautumista muista. "Olimme ylpeitä siitä, että olimme saaneet aikaan noin hienon yhteishengen. "- "Olen näyttänyt itselleni pystyväni tekemään jotakin uutta, ja ehkä vähän pelottavaakin, mutta olen sen kuitenkin uskaltanut tehdä ja osaan ja uskallan näyttää sen myös muille ihmisille." Edelleen tutkijoiden ennakoinnin mukaan aineistosta eriytyi ylpeyden tunteen toinen perusproblema- tiikka: onko tunne sisäisesti hyväksytty vai ei, ja missä määrin sitä on sallittua näyttää ulospäin. Tässä tutkijat havaitsivat mielenkiintoisen eron. Pääkaupunkiseudun ihmiset pitivät huomattavasti muita useammin ylpeyden tunnetta sisäisesti hyväksyttävänä ja samalla myös ilmaistavana. Suomalaista sielunmaisemaa kuvasti myös havainto, että ylpeyden näyttämistä ulkopuolisille ei läheskään aina pidetty viisaana ja sallittuna, vaikka tunne itselle koettiinkin hyväksytyksi. Ikonen ja Varila-Ikonen päättelevät tästä, että lapsuuden perheen ja elinympäristön alueelliset ja kulttuuriset piirteet mallittavat voimakkaasti myös ylpeyden tunteen esiintymistä. Ilmiö perustuu heidän mukaansa ennen kaikkea siihen sosiaaliseen merkitykseen, jonka lähipiirin auktoriteetit tunteille ja tässä tapauksessa ylpeyden tunteille antavat.

Tutkimuksen empiiristä osaa edeltää laaja ja yksityiskohtainen teoreettisten näkökulmien pohdinta, jonka avulla ylpeyden tunnetta pyritään haarukoimaan useilta eri suunnilta. Tämän tarkastelun myötä ylpeys saa määrittelynsä: ylpeys on sosiaalisen todellisuuden määrittämä, arvoihin ja arvostuksiin liittyvä, kognitiivisesti painottunut, nimetty ja tulkittu tunnekokemus, joka voi ilmetä joko hetkellisenä tunnetilana, pitempikestoisena mielialana tai luonteeltaan melko pysyvänä temperamenttina.

Varila ja Varila-Ikonen jatkavat jäsentelyään toteamalla, että ylpeydellä on aina ilmaistavis- 
sa oleva kohde, jotakin mistä ollaan ylpeitä (toisin kuin esimerkiksi hahmoltaan epäselvällä poreilevan ilon tunteella). Ylpeyden kokemiseen liittyvä fysiologinen virittäytyminen on useimmiten vähäistä eikä se syrjäytä kognitiivisia prosesseja. Ylpeydentunnetta viriämistä eivät muut juurikaan voi suoraan päätellä henkilön ulkoisesta käyttäytymisestä.

\section{AMMATTIYLPEYS TUNNE- TEORIOIDEN VALOSSA}

Näiden määrittelyn pohjalta tutkijat punnitsevat ylpeyttä eri tunneteorioitten valossa. Naturalismin mukaan ylpeys ei kuulu ihmisen perustunteiden joukkoon, mutta se voidaan ihmissuhteitten kentässä sijoittaa häpeän tunteen vastatunteeksi. Kognitiivisen tunneparadigman mukaan ylpeyden tunne ei synny yksilössä reaktionomaisena (kuten ilo tai pelko) vaan se edellyttää aina edeltäkäyvää, aikaisemmin omaksuttua skeemaa, jonka välityksellä tunnetila viriää kuin 'hitaan polun kautta'. Konstruktivistisen tunneparadigman suunnasta ylpeys nähdään puhtaasti kulttuurisidonnaisena, sosiaalisesti opittuna ilmiönä, joka viestii yhteisön arvoja, normeja ja usein tiedostamattomiakin valtarakenteita. Tutkijat päätyvät kuitenkin toteamaan, että kaikki tunneteoreettiset paradigmat pitävät tunteita liian mekaanisina kokonaisuuksina, jotka tavalla tai toisella paketoidaan yksilöön sosialisaatioprosessin vaiheissa.

Mikään käsitellyistä tunneteorioista ei siten kykene selittämään, millainen on ylpeyden psyykkinen dynamiikka tai mihin ihminen itse asiassa tarvitsee ylpeyden kokemusta. Sen sijaan Ikonen ja Varila-Ikonen toteavat, että oppimisteorioitten avulla voidaan jo helpommin ymmärtää monia ylpeyden tunteen ilmenemiseen liittyviä piirteitä. Yhtäältä yksilö siis rutinoituu kulttuurisessa ehdollistumisprosessissaan hyväksymään elämänpiiriin luonnostaan liittyviksi tietyt ylpeyden kokemisen tunnesäännöt. Toisaalta klassisen ehdollistumisen mekanismit ovat voimissaan työyhteisökulttuurien usein hämärästi tiedostetuilla pelikentillä ja ihmisen tietoisuuden sivussa toimiva "tunnetutka" kerää ja analysoi siellä tarjolla olevia ärsykkeitä väsymättömästi ja tuottaa näin joko sitoutumisen tai vieraantumisen kokemuksia. Ammatillisen ylpeyden tai työnilon kokemusta ei ehdollistumisteoria tosin onnistu selittämään, mutta se auttaa ymmärtämään, miksi nuo kokemukset joskus ovat tarjolla ja joskus taas niin dramaattisesti menetetään kehnossa työilmapiirissä.

\section{YLPEYS OPPIMIS- TEORIOIDEN VALOSSA}

Oppimisteorioita tarkastellessaan tutkijat päätyvät arvioimaan, että kognitiivisen oppimisteorian ajatukset oivaltavasta oppimisesta ja kognitiivisten karttojen merkityksestä soveltuvat myös ylpeyden tunteen ymmärtämiseen. Koska ylpeyden tunne ei luonteeltaan ole primääri perustunne, sen oppiminen edellyttää jo pitkälle kehittynyttä ajattelukykyä ja taitoa tarkastella itseä muiden silmin. Ylpeyden kokemisen, tulkitsemisen ja ilmentämisen säännöt opitaan siis oman varhaisen perhetilanteen piirissä. Tähän oppimiseen vaikuttavat monet kulttuuriset, uskonnolli- set ja yhteiskunnalliset tekijät.

Yhtäältä ylpeyden tunne edellyttää aina kytköksen johonkin yksilölliseen tai yhteiseen aikaansaannokseen. Toisaalta kulttuuriset eroavaisuudet ovat suuria siinä, kuinka tätä ylpeyttä pitäisi kokea tai ilmaista. Näiden menettelytapojen hienosäätö onnistuu aikuisiälläkin työelämän kulttuurien vaihtelussa, mutta jos yksilössä ei jo varhaislapsuudessa ole päässyt syntymään aitoa itsekunnioitusta, ei aitoa tervettä ylpeyttä opita myöhemminkään tuntemaan. Kodin varhaiset kokemukset ja niiden tunnesisältö ja koherenssi vaikuttavat implisiittisen muistin välityksellä käyttäytymiseen ja silloin kognitiivinen päättely syrjäytyy. Yksilön sosiaalihistoriasta riippuu minkälaisia mahdollisuuksia yksilöllä on ylipäätään kokea sosiaalisia roolinottoemootioita, esim. ylpeyttä tai häpeää. Näin tutkijat päätyvät toteamukseen, että myös tunteiden naturalistinen tulkinta on käyttökelpoinen ylpeyden tunteen psykodynamiikan ymmärtämisessä.

\section{LUONTEENPIIRRE?}

Tutkijat tiivistävät ylpeyttä koskevan teoretisointinsa lievään kulttuuripessimismiin: Vaihtoehdoton ja luonnollinen, lapsuudesta asti itsestäänselvä tai kaikkien hyväksymä menettely juurtuu yksilön mielessä käyttäytymisen pysyväksi luonnehahmoksi. Elämän ja koulutuksen myötä uusi aines lomittuu siihen, mutta ydin säilyy muuttumattomana.

Ei siis ole ihme, että Varilan ja Ikonen-Varilan mukaan yhteiskunnassa ei ole tarpeen keskittyä samuutta tuottavan ylpeyden tunteen edistämiseen 
kasvatuksessa - se syntyy sosialisaatioprosessissa luonnostaankin. Sen sijaan yhteisön pitäisi tukea yksilön kyky tuntea ylpeyttä omasta itsestään ja taitavuudestaan. Tämän sietäisi tulla tutkijoiden tulkintansa mukaan avoimemmin hyväksytyksi piirteeksi, varsinkin jos erottautuminen merkitsee rohkeata erottautumiseta ryhmäpaineesta ja pidättäytymistä moraalisesti arveluttavista tai tuomittavista ammattikäytännöistä.

Juha Varila on kriittinen kaikenlaisen sinisilmäisen työssäoppimisen retoriikan irvailija ja uusliberalistisen koulutuspolitiikan ja työmarkkinoiden ylikorostuneen aseman arvostelija. Kumpikaan ei ole uutta, mutta vaatii silti sinnikkyyttä konkretisoida kritiikki merkkihuoltamoiden työnjäljen arvostelun tasolle. Näin tutkijat välillä antautuvat filosofiseen sosiaalisten lainalaisuuksien pohdintaan tai kulkee tieteellisen tutkimuksen ja ajankohtaispamfletin tyylillisessä välimaastossa. Kiinnostavimmillaan Varilat ovatkin pohtiessaan pysyvyyden ja muutoksen problematiikkaa postmodernissa ajanvirrassa tai vertaillessaan oppivan organisaation retoriikkaa kommunisti- seen työn sankarin ihannointiin.

\section{YHTEISKUNNALLISEN KEHITYKSEN OIVALTAVA TULKITSIJA}

Tutkimuksen tavoitteet oli määritelty kolmijakoisesti: tutkijat halusivat arvioida ylpeyden tunteen merkitystä ihmisen psykodynamiikassa, tarkastella ja arvottaa ylpeyden tunteen merkitystä yhtenä tunnekasvatuksen tekijänä sekä pohtia ylpeyden ja kunnian tunteen merkitystä työelämässä - erityisesti henkilöstön ja organisaation kehittämisen kannalta. Kahteen ensimmäiseen teemaan tutkimus pureutuu kiitettävästi. Kolmas tavoite saavutetaan vain osittain. Avoimeksi jää, mitä käytännön apuvälineitä ammattiylpeyden viriämisen ja esiintymisen parempi ymmärtäminen tulee tarjoamaan aikuiskasvatuksen didaktiikalle? Varila ja Ikonen-Varila joutuvat itsekin lopuksi toteamaan, että käytettävissä olevan aineiston pohjalta kysymys ammattiylpeyden ja ylpeyden suhteesta jää avoimeksi. Tekijät pitävät teostaan polunpään avaajana ja arvelee myöhempien tutkimusten selvittävän laajemmin ja syvemmin ylpeyden problematiikkaa. Ensi- sijaisesti tutkimus vahvistaakin kuvaa Juha Varilasta paitsi polunavaajana uusiin tutkimuksellisiin maailmoihin myös yhteiskunnallisen kehityksen oivaltavana tulkitsijana.

Teoksen painokuntoon saattamista lienee saatellut melkoinen kiire, koska paikoitellen tekstiin jääneiden lyöntivirheiden melko suuri määrä sitoo turhan paljon lukijan huomiota. Samoin tutkimusta varten kootun esseeaineiston luonnetta koskevassa pohdinnassa lopullisen tekstin sekaan on vahingossa unohtunut katkelma aikaisempaa tekstiversiota. Kertaus on kuitenkin kaiken oppimisen äiti ja tällaisenaan Variloitten raportti on myös kuvausta tutkimustekstin muokkausvaiheista.

\section{Heikki Salomaa}

Joensuun yliopiston kasvatustieteen laitoksen työnilo-tutkimuksen, Juha Vari-la \& Kati Lehtosaari (2001) "Työnilo - Ahkeruudella ansaittua, sattuman synnyttämää vai oppivan organisaation vaatimaa" esittely ja arvio on lehden netissä osoitteessa sivistys.net > Aikuiskasvatus > Aikuiskasvatuksen uutuuskirjallisuutta. Arvion on kirjoittanut Anna-Liisa Nieminen. 